\title{
Motivations Of Public To Private Transactions: An International Empirical Investigation
}

\author{
Aurélie Sannajust, COACTIS - Université de Saint-Etienne, France \\ Mohamed Arouri, EDHEC Business School, France \\ Frédéric Teulon, IPAG Business School, France
}

\begin{abstract}
This article contributes to the financial literature by investigating the motivations of Public to Private transactions in an international perspective (Europe, USA and Asia). We consider seven main possible motivations: tax savings, incentive realignment, control, free cash-flow, growth of prospects, takeover defense and undervaluation. Our empirical findings suggest that low growth prospects, low liquidity and high free cash-flow are the three main motivations for a Public to Private transactions. However, regions show some particularities such as importance of family block-holders in Europe and importance of the level of taxation in Asia.
\end{abstract}

Keywords: Public to private, Motivations, Logistic regression.

\section{INTRODUCTION}

C $\mathrm{n}$ the recent years, we have observed a trend of companies to leave the stock exchange, this phenomenon is designed by public to private $\left(\mathrm{PtoP}^{1}\right)$. This trend has been such that Jensen (1989) foresaw the end of listed companies. In the USA, much research has been developed to study public to private transactions. It is also the case in Europe and more precisely in the United Kingdom. The aim of this paper is to understand the motivations of PtoP transactions. To this end, we examine the main determinants of both economic and corporate governance that may affect the decision for a firm to be delisted. The contribution of the paper is to offer the first international empirical investigation of going private transactions over the period $2000-2010$. The results are expected to enable us to determine the main factors for firms to go private in different geographical areas.

We focus on seven main possible reasons: tax savings, incentive realignment, control, free cash-flow, growth of prospects, takeover defense and undervaluation. Towards this end, we make use of parametric and nonparametric tests applied to two samples, one of PtoP transactions and another which represents the control sample. At the end, we will be able to determine the profile of all Public to Private transactions for each geographical area.

We first describe the main possible determinants that lead firms to go private in order to present the hypotheses. Then we present our sample and methodology. Our sample is composed of the USA, Europe (France, Germany, Italy, Netherlands, Spain, Sweden and United Kingdom) and Asia (North, Center and South). We have retained 535 transactions from 2000 to 2010 . This sample represents $82 \%{ }^{2}$ of the world population of PtoP. The control sample is determined by including different criteria (the technique of pairing): the size measured by the amount of sales, the same location, the same business sector and the stock quotation. The number of companies is identical to the sample of PtoP. Several databases are used to determine the two samples: OSIRIS, ORBIS, and Thomson One Banker.

\footnotetext{
${ }^{1}$ Note that in American literature, the term joint PtoP and LBO is often used. Indeed, as the PtoP, LBOs are financed largely by debt. The distinction between the two is explained in terms of composite mode of financing the debt: for example, PtoP with more than $50 \%$ debt financing of the LBO debt. The distinction is quite subtle, we should analyze the financial structure of each company, which is extremely difficult, which is why PtoP and LBO can be used simultaneously. When we employ LMBO, we refer to the redemption of society made by its management team.

${ }^{2}$ Source: Thomson One Banker.
} 
Our findings reveal that the typical profile of public to private transaction is composed of low managerial share, low representation of control blocks, significant cash-flow, weak growth outlook, an undervaluation of the company and low liquidity. Moreover, some characteristics of geographical areas seem to be relevant. For example, in Europe, family block-holder has an important role whereas it does not play a significant role in the USA. In Asia, the level of taxation is important.

The remainder of the paper is organized as follows. Section 2 presents the main possible motivations of Public to Private transactions. Section 3 describes the construction of the database and the methodology used. Section 4 presents the results of the univariate and multivariate analyses. Section 5 discusses results for each motivation. Section 6 concludes.

\section{LITERATURE REVIEW AND TESTABLE HYPOTHESES}

The main driver for value creation in Public to Private transactions resulted from a more efficient and effective management after the transaction. Indeed, the manager has to deal with huge levels of debt and very often also holds a big stake in the firm, which gives him incentives to work hard and to generate large cash-flows. This idea is tested in the following hypotheses.

\subsection{Tax Saving}

In general, we remark a massive use of debt for Public to Private transactions. This loan can offer the necessary money to realize the montage. It has two particular goals: on the one hand it allows the firm to realize the transaction and on the other hand it allows a tax deduction through interest on loan which is an important source of wealth (Lowenstein, 1985). This deduction can pay the debt and the remuneration for the shareholders via premium. For the period from 1980 to 1986, Kaplan (1989b) estimated that the tax saving of PtoP in the United States is between 21 and $72 \%$ of premiums paid to shareholders to take a company that withdraws from the listing market. Although this tax benefit is available to purchasers of the company, it is the shareholders of the target company who benefit the most through the premiums that are paid. Consequently, the wealth of shareholders of Public to Private is positively correlated with an important rate of taxation. Two variables measure the tax saving: taxation (the level of taxation) and gearing (financial debt/shareholder funds).

H1: Companies that benefit low leverage of pre-transaction and important rate of taxation are more likely to leave the quotation.

The main driver for value creation in these transactions resulted from a more efficient and effective management after the transaction. Indeed, the manager has to deal with huge levels of debt and very often also holds a big stake in the firm, which gives him incentives to work hard and to generate large cash-flows. To define the hypotheses we test, we explicitly base the following discussion on our previous work, Sannajust (2010).

\subsection{Incentive Realignment}

"The views from Adam Smith (1776), Berle \& Means (1932) on the divergence of interests between managers and shareholders are formalized by Jensen \& Meckling (1976). In this model, when a manager assigns a portion of its receivables to outside investors, the marginal costs of pecuniary benefits reduce only a fraction. Finally, manager increases his private interests which decrease the value of the firm. The private equity firms have many mechanisms for reward good managers for their good performance when they engage in a public to private transaction (Fenn, Liang \& Prowse, 1995). Private Equity firms (the principal) try to realign the interests of managers (agents) with them. The hypothesis of realignment of interest says that the wealth of shareholders of a PtoP is largely the result of a system to meet the interests of the agent and principal" (Sannajust, 2010).

As we noticed is that "the reunification of ownership and control will improve the incentive structure and is expected to increase managerial effort to maximize firm value. However, the effects of the realignment hypothesis of interest at a high level of managerial participation are contested because of the entrenchment effect (Morck, Schleifer \& Visny, 1998; McConnel \& Servaes, 1990) that may prevent or delay restructuring leaders and also the restructuring of the company (Franks, Mayer \& Renneboog, 2001)" Sannajust (2010). 
We use a dummy variable (managerial ownership) which is equal to 1 if the managers hold more $25 \%$ of share of the company.

H2: Companies whose interest's actors diverge are more likely to delist.

\subsection{Control}

"Easterbrook \& Fischel (1983), Grossman \& Hart (1988) explained why shareholders in individual companies with dispersed ownership can underinvest in monitoring (the problem of free-rider). After an LBO (leveraged buyout), the property of the company is much more concentrated by giving stronger incentives for investors (the principal) and more information to invest in monitoring management (Maug, 1998; Admati,). Furthermore, in judging the viability and success of acquisitions famous, DeAngelo, H., DeAngelo, L. \& Rice (1984) argued that investors may have a comparative advantage in the monitoring task (Fenn et al., 1995). By this, it means that the public to private transaction can create value by solving the problem of free-rider on the control of managers (the agent)" (Sannajust, 2010).

We can argue that "The hypothesis of control argues that the wealth obtained by shareholders depends largely on the outcome of the supervision system imposed by the management team in place. Although the literature on agency costs provides three sources for the wealth of public to private transaction, this practice is difficult to make. Lowenstein (1985) explained this fact with the theory of the stick and the carrot: carrot represents the increase shares that managers hold allowing them to enjoy more benefits. The stick is when companies use a massive debt forcing them to reduce benefits that previously were bunched managers in order to manage the company effectively avoiding bankruptcy (Cotter \& Peck, 2001)" (Sannajust, 2010).

We consider that "Control" is divided into three parts:

(1) Institutional Block-holder: this variable is equal to 1 when this block-holder has at least $5 \%$ of share of capital otherwise it is 0 .

(2) Corporation Block-holder: this variable is equal to 1 when this block-holder has at least $5 \%$ of share of capital otherwise it is 0 .

(3) Family Block-holder: this variable is equal to 1 when this block-holder has at least $5 \%$ of share of capital otherwise it is 0 .

H3: Companies whose capital is dispersed are more likely to delist.

\subsection{Free Cash-Flow}

"Jensen (1986) defined free cash-flow as "cash-flow in surplus from which is required to fund all projects that have a positive net present value". In using empirical results on executive pay and performance companies made by Murphy (1985), Jensen argued that managers have incentives to keep resources and to increase the firms beyond its optimal size, hence the name "empire building" which represents the direct conflict with the interests of shareholders. In exchanging debt cons of capital across highly leveraged, credible managers pay their future free cash-flow instead of retaining their own interest in project with a negative net present value (Jensen, 1986). However, linking debt and motivation of managers can lead to results in significant agency costs (Calcagno \& Renneboog, 2007)" (Sannajust 2010).

Free Cash-flow is used to study this hypothesis: the level of Free Cash-flow is approximated by operating income before depreciation and amortization minus tax, interest and dividend payments (Lehn \& Poulsen, 1989).

H4: Companies with strong Free Cash-flow are more likely to delist. 


\subsection{Growth Prospects}

"Another analysis was conducted on growth prospects for public to private transactions. According to Jensen (1986), companies that have low growth prospects appear as potential candidates to withdraw from the stock quote because they imply a weak management and decision making suboptimal. Lehn \& Poulsen (1989) also confirmed that the companies withdrew from the quotation, have low prospects growth. A variable measuring growth prospects has been found with the ratio of Tobin ( $\mathrm{Q}$ of Tobin) which measures the relationship between the market value of the firm and replacement cost of assets. A low ratio indicates low growth prospects and significant agency costs whereas a large value indicates substantial growth prospects and lower agency costs" (Sannajust, 2010). by total assets.

We use $Q$ ratio as the variable to estimate growth prospects. It is defined as market capitalisation deflated H5: Companies with low growth prospects are more likely to leave the quotation.

\subsection{Takeover Defense}

"Another reason which may lead to the launch of a public to private transaction is the fear of being redeemed. Lowenstein (1985) noted that for many companies that withdraw (Management Buy-Outs, MBO), it is a strategic defence against a final hostile offer to shareholders or cons of bidding. For fear of losing their jobs, managers prefer to leave the exchange. Moreover, when managers have a very important part in corporate capital, it is unlikely to be bought by others (Jensen \& Ruback, 1983). However, maintain control of society can lead managers to find themselves in a difficult situation because they have invested their entire personal wealth in society (Halpern, Kieschnick \& Rotenberg, 1999; Hubbard \& Palia, 1995). Numerous studies have analysed this case" (Sannajust, 2010).

Some examples can be quoted:

"In UK, Kennedy \& Limmack (1996) found that $40.14 \%$ of companies redeemed in the form of traditional buyouts, have replaced their CEO in the first year following the takeover and $25.7 \%$ did so during the second year. In the USA, Martin \& McConnel (1991) found that 41.9\% of teams' leaders leave their jobs in the first year of transaction. Therefore, an MBO protects the leaders of this phenomenon. Management takes a large share of the company in order to hedge against any possible hostile takeover. This hypothesis of protection against a hostile takeover suggests that premiums reflect the fact that the management team may have the intention to repurchase shares from other shareholders to protect itself against an unsolicited takeover bid" (Sannajust, 2010).

We use a dummy variable (Prior Takeover Defence) which is equal to 1 when the firm faces takeover one year before going private.

H6: Companies which have been the subject of a partial takeover are more likely to delist.

\subsection{Undervaluation}

"As a firm represents a "portfolio" (Kieschninck, 1989), there are informational asymmetries between managers and outside investors regarding the maximizing of the value of corporate assets (Roll, 1977; Lehn, Netter $\&$ Poulsen, 1990). However, it is impossible for managers who have private information to realize that share price of the company is undervalued compared to the real potential of the latter. This problem may be exacerbated when the listed companies, mostly small, have difficulties in the finance market to grow, which is difficult to attract the interest of investors. This lack of interest for these companies creates a lack of liquidity and involves a reduction in the value of the company which leads to exit the stock exchange (Mehran \& Peristinami, 2006)" (Sannajust, 2010).

We can make a reference from Lowenstein (1985) who explained that when managers represent the main part in control of the company, they can use specific methods in terms of technical and financial accounting to 
depreciate the stock price before the announcement (Schadler \& Karns, 1990). By manipulating the dividends, they refuse to meet analysts because managers use the asymmetry information to their advantage (Sannajust, 2010).

"DeAngelo (1986) found no evidence in terms of manipulations that could be performed by managers. However, Harlow \& Howe (1993), Kaestner \& Liu (1996) confirmed that in the case of MBO, there are important stock purchases made before going private.. The hypothesis of undervaluation suggests that the wealth obtained by the shareholders is from the undervaluation of corporate assets. Moreover, for investors, the increasing of liquidity in integrated shares of the company is a key factor for listed companies (Amihud \& Mendelson, 1988). Conversely, the listed company with small market shares will have low liquidity and financial problems and they will have to remain listed. They will consider as real targets. Therefore, firms in quotation which have low financial perspective and low liquidity will have a high probability to delist and to become private" (Sannajust, 2010).

We use two variables: first, PER (Price Earnings Ratio) to estimate the undervaluation and second, liquidity (assets minus stock divided to financial debt).

H7: Companies which are undervalued or have low liquidity are more likely to delist.

\section{DATA AND METHODOLOGY}

\subsection{Sample Control: Methodology And Statistics}

For our analysis, we need a PtoP sample as well as a sample control which is composed of listed companies. To construct this sample control, we employ a specific method, the technique of pairing: three parameters are retained: i. the size (measured either by turnover or total assets), ii- the location (firms have to be located in the same area activity), and iii. the stock quotation (firms have to be listed at least a year). The choice of this technique is justified by the fact that it allows to assess the probability of occurrence of an event and differentiate firms in Public to Private companies to remain listed. The development of the control sample is performed based on three essential characteristics: business sector and the amount of sales and period:

- Business sector: this category includes major business areas of the company. This allows us to consider, first, the life cycle industrial and secondly, between the particular industries in terms of financial structures. The database Thomson One Banker provides SIC sector code, the pairing was done using it. In most cases, firm control sample, that is to say the firm control, was selected by referring to the first two digits of SIC code.

- The amount of sales: it is a criteria representative of the size factor. We make the hypothesis that the local asset is a good indicator of company size in the sense that it includes all investors industrial, commercial and financial. Moreover, the choice of this criterion allows us to avoid the bias with the difference in size between firms in the same sector of activity and take the fact that SMEs do not have the same behavior as the major companies. Therefore, the firms listed have been selected, that is to say "firms witnesses", and should have the nearest total assets to those the company studied. To make this control sample, a rigorous methodology must be respected. We based on a methodology that has already been applied by several authors, such as Weir and al. (2005).

- The period: economic conditions are important so we match the control sample in relation to the same year as firm in the PtoP sample.

Moreover, a final test is performed to verify if all the firms selected of our control sample remained listed at least two years after the announcement of a going private. Our sample consists of 535 companies: 102 in Europe, 153 in the United Kingdom, 209 in the United States and 71 in Asia. 


\subsection{Analysis}

\subsubsection{Presentation Of The Methodology}

Our statistical analysis is performed using two samples:

- $\quad$ Sample 1: it includes all the PtoP from 2000 to 2010 for Europe, the United Kingdom, the United States and Asia. The number of companies amounted to 535.

- $\quad$ Sample 2 called control sample, it consists of companies that are remained publicly traded from 2000 to 2010 for the four geographical areas. A methodology is followed to fully optimize the development of this sample (company size, industry...). The number of companies is identical to the sample 1. For the control sample, we used ORBIS which brings together financial data from annual reports listed companies. Thus all the variables selected were identified for both samples.

\subsubsection{Parametric Test}

Before using the difference in means test, three precautions should be taken:

- Ensure that the distribution of the sample is consistent with the hypothesis Gaussian distribution of the variable (normality test).

- $\quad$ Check the homogeneity of variances of all samples.

- $\quad$ Check the size of the sample (over 30).

The three stages have been completed; we apply the t-statistics for all samples. Applying the test of differences in means can be realized. It aims to whether the means of the variables of the two samples are significantly different.

\subsubsection{Non-Parametric Test}

We also use a non-parametric test, Wilcoxon test, also called sign test and rank, in order to compare characteristics of two distributions. This test is an alternative non-parametric test of t-Student we just presented. The Wilcoxon test is based only on the order comments on the two samples. It also helps to provide some response to relevant issues such as "the shape of the distribution is identical?", "is there a significant difference between the central tendencies of two distributions?". It takes into account both the rank and signs of each element in the sample and not based on any assumption regarding the probability distribution.

\subsubsection{The Logit Model}

Our model is presented in the following form:

$Z=\beta_{0}+\beta_{1} T+\beta_{2} G+\beta_{3} M+\beta_{4} I+\beta_{5} C+\beta_{6} F+\beta_{7} F C F+\beta_{8} Q+\beta_{9} P T I+\beta_{10} P E R+\beta_{11} L+e$

Table 1 shows the different variables used in the model and their respective definitions. All data for variables were taken one year before the release of the award of the company which is the last year before delisting. 
Table 1: Variables

\begin{tabular}{|c|c|c|}
\hline Names & Variables & Definitions \\
\hline$T$ & Taxation & Amount of taxation (in percentage) \\
\hline$G$ & Gearing & Leverage: ratio between financials debt to shareholder funds \\
\hline$M$ & Managerial ownership & $\begin{array}{l}\text { Managerial ownership ( } 1 \text { : when the equity held by managers represents over } \\
25 \% \text { of shares of the company; } 0 \text { : otherwise) }\end{array}$ \\
\hline$I$ & Institutional block-holder & $\begin{array}{l}\text { 1: when the share of institutional shareholders is at least equal to } 5 \% \text { of shares } \\
\text { of the company; } 0 \text { : otherwise }\end{array}$ \\
\hline$C$ & Corporation block-holder & $\begin{array}{l}1: \text { when the share of corporation shareholders is at least equal to } 5 \% \text { of shares of } \\
\text { the company; } 0 \text { : otherwise }\end{array}$ \\
\hline$F$ & Family block-holder & $\begin{array}{l}\text { 1: when the share of family shareholders is at least equal to } 5 \% \text { of shares of the } \\
\text { company; } 0 \text { : otherwise }\end{array}$ \\
\hline$F C F$ & Free cash-flow & $\begin{array}{l}\text { It is approximated by operating income before depreciation and amortization } \\
\text { minus tax, interest and dividend payments (Lehn \& Poulsen, 1989). }\end{array}$ \\
\hline$Q$ & $Q$ ratio & $Q$ ratio: is defined as market capitalisation deflated by total assets \\
\hline$Q 1 / Q 2$ & $Q 1 / Q 2$ & $\begin{array}{l}Q 1 / Q 2 \text { : the } Q \text { ratio in the year before going private (at the last published } \\
\text { accounts) divided by the } Q \text { ratio in the previous year }\end{array}$ \\
\hline$Q 1 / Q 3$ & $Q 1 / Q 3$ & $\begin{array}{l}Q 1 / Q 3 \text { : the } Q \text { ratio in the year before going private divided by the } Q \text { ratio two } \\
\text { years before }\end{array}$ \\
\hline$L Q * H F C F$ & $\begin{array}{l}\text { Low } Q \text { ratio } * \text { high free } \\
\text { cash-flow }\end{array}$ & $\begin{array}{l}L Q^{*} H F C F: \text { is a dummy variable that takes a value of one if a firm had below } \\
\text { median } Q \text { and above median free cash-flow and zero otherwise }\end{array}$ \\
\hline SIZE & Ln (Sales) & Ln (Sales) \\
\hline$P T I$ & Prior takeover interest & $\begin{array}{l}\text { Prior takeover interest: a dummy variable which equals } 1 \text { if there has been any } \\
\text { takeover interest in the year leading up to the PTP announcement }\end{array}$ \\
\hline$P E R$ & Price earning ratio & Price earning ratio \\
\hline$L$ & Liquidity & Ratio of assets less stock on financial debt \\
\hline
\end{tabular}

\section{EMPIRICAL RESULTS}

In this section, we present our empirical findings region by region.

\subsection{Europe}

In panel A, we note that the structure of ownership and control for public to private companies in Europe is largely composed of managers and the family block-holder (Andres, 2008; Faccio and Lang, 2002). The result can be explained by the European Industrial which composes of nearly $90 \%$ of SMEs.

In panel $\mathrm{B}$, we observe that the undervaluation, the growth prospects and the level of liquidity are three elements which characterize highly PtoP deals. Indeed, the data reveal that the growth prospects of the company measured by the $\mathrm{Q}$ ratio are much lower for the PtoP belonging to the control sample (0.83 against 1.45$)$. Underpricing is another criterion that qualifies the PtoP. The results are suggestive, 15 for PtoP cons 27 for Control Sample (CS). Similarly, the lack of liquidity is also part of criteria that characterize PtoP from other companies. 
Table 2: Results for Europe (102 observations)

\begin{tabular}{|c|c|c|c|c|c|c|}
\hline $\begin{array}{c}\text { Variables } \\
\end{array}$ & PtoP Mean & Median & SC Mean & Median & t value & z statistic \\
\hline \multicolumn{7}{|c|}{ Panel A: Property and Control } \\
\hline Managerial Ownership & 0,65 & 1 & 0,85 & 1 & $-2,682 * * *$ & $-2,679 * * *$ \\
\hline Institutionnal Block-holder & 0,61 & 1 & 0,75 & 1 & $-2,697 * * *$ & $-2,643 * * *$ \\
\hline Corporate Block-holder & 0,58 & 1 & 0,72 & 1 & $-2,791 * * *$ & $-2,728 * * *$ \\
\hline Family Block-holder & 0,64 & 1 & 0,84 & 1 & $-2,904 * * *$ & $-2,876 * * *$ \\
\hline Takeover Defence & 0,56 & 1 & 0,52 & 1 & 1,036 & 1,123 \\
\hline \multicolumn{7}{|l|}{ Panel B: Performance } \\
\hline Taxation & 1,21 & 1,17 & 1,18 & 1,08 & 1,026 & 1,103 \\
\hline Gearing & 1,42 & 1,38 & 1,45 & 1,39 & $-1,115$ & $-1,112$ \\
\hline Free Cash-flow & 4,55 & 4,43 & 3,77 & 3,70 & $2,169 * *$ & $2,214 * *$ \\
\hline $\mathrm{Q}$ ratio & 0,83 & 0,81 & 1,45 & 1,42 & $-3,987 * * *$ & $-3,521 * * *$ \\
\hline Q1/Q2 & 0,91 & 0,87 & 1,05 & 1,03 & $-3,362 * * *$ & $-3,214 * * *$ \\
\hline Q1/Q3 & 0,86 & 0,85 & 1,12 & 1,09 & $-3,556 * * *$ & $-3,514 * * *$ \\
\hline LQ*HFCF & 0,37 & 0,25 & 0,24 & 0,16 & $2,105 * *$ & $2,034 * *$ \\
\hline PER & 15,14 & 14,52 & 26,78 & 25,92 & $-2,412 * *$ & $-2,376^{* *}$ \\
\hline Liquidity & 1,45 & 1,38 & 2,09 & 1,96 & $-2,654 * * *$ & $-2,698 * * *$ \\
\hline
\end{tabular}

PtoP : Public to Private; SC : Sample Control

Notation: $* * * * *, *$ represent significance level up to $1 \%, 5 \%$ and $10 \%$.

Taxation: amount of taxation (\%); Gearing: ratio between financials debt to shareholder funds, Managerial ownership: 1: when the equity held by managers represents over $25 \%$ of shares of the company; 0 : otherwise; Institutional block-holder: 1: when the share of institutional shareholders is at least equal to $5 \%$ of shares of the company; 0: otherwise; Corporation block-holder: 1: when the share of corporation shareholders is at least equal to $5 \%$ of shares of the company; 0: otherwise; Family block-holder: 1: when the share of family shareholders is at least equal to $5 \%$ of shares of the company; 0: otherwise; Free Cash-flow: It is approximated by operating income before depreciation and amortization minus tax, interest and dividend payments (Lehn \& Poulsen, 1989); Q ratio: market capitalisation deflated by total assets; Q1/Q2: $Q$ ratio in the year before going private (at the last published accounts) divided by the $Q$ ratio in the previous year; Q1/Q3: $Q$ ratio in the year before going private divided by the $Q$ ratio two years before; $\boldsymbol{L Q} * \boldsymbol{H} \boldsymbol{F C F}$ : is a dummy variable that takes a value of one if a firm had below median $Q$ and above median free cash-flow and zero otherwise; Ln (Sales); Prior takeover interest: dummy variable which equals 1 if there has been any takeover interest in the year leading up to the PTP announcement; Price earnings ratio; Liquidity: Ratio of assets less stock on financial debt.

\subsection{United Kingdom}

In Panel A, the Institutional block-holder is part of a key element that characterizes UK Public to Private (Weir et al., 2005). This is confirmed by the result (0.69) which is higher compared to that observed for other blocks of the sample to Public Private (0.56 for the corporate block-holder; 0.51 for Family block). We also note that the Institutional block-holder plays an important role for the public to private and for corporate remained in stock quotation. However, we find that the latter is higher than observed in Europe. Moreover, the family block-holder is much less present in public to private in the United Kingdom than in Europe. However, no significance was found. The results are relatively near ( 0.64 for Public to Private against 0.84 for the control sample). We cannot confirm that this block-holder is one of PtoP characteristics. The takeover is significantly higher for PtoP companies, they are more subject to supply low growth prospects and liquidity compared to listed companies ( 0.85 against 1.47 for the growth prospects and 1.48 cons 2.02 for liquidity). They are ideal takeover targets.

In panel B, the level of FCF, growth prospects and lack of liquidity are also three major elements that characterize PtoP. The results are broadly similar to those found in the rest of Europe. 
Table 3: Results for UK (153 observations)

\begin{tabular}{|c|c|c|c|c|c|c|}
\hline Variables & PtoP Mean & Median & SC Mean & Median & t value & z statistic \\
\hline \multicolumn{7}{|c|}{ Panel A: Property and Control } \\
\hline Managerial Ownership & 0,51 & 1 & 0,68 & 1 & $-2,426 * *$ & $-2,387 * *$ \\
\hline Institutionnal Block-holder & 0,69 & 1 & 0,81 & 1 & $-2,215^{* *}$ & $-2,134 * *$ \\
\hline Corporate Block-holder & 0,56 & 1 & 0,65 & 1 & $-2,196^{* *}$ & $-2,102 * *$ \\
\hline Family Block-holder & 0,51 & 0 & 0,53 & 1 & $-1,102$ & $-1,006$ \\
\hline Takeover Defence & 0,57 & 0 & 0,55 & 1 & 1,126 & 1,101 \\
\hline \multicolumn{7}{|c|}{ Panel B: Performance } \\
\hline Taxation & 1,91 & 1,78 & 1,87 & 1,83 & 1,556 & 1,519 \\
\hline Gearing & 1,23 & 1,18 & 1,26 & 1,20 & $-1,272$ & $-1,217$ \\
\hline Free Cash-flow & 4,46 & 4,35 & 4,12 & 4,03 & $2,456^{* *}$ & $2,418 * *$ \\
\hline Q ratio & 0,85 & 0,79 & 1,47 & 1,38 & $-4,056^{* * *}$ & $-3,875 * * *$ \\
\hline Q1/Q2 & 0,97 & 0,92 & 1,12 & 1,08 & $-3,915 * * *$ & $-3,723 * * *$ \\
\hline Q1/Q3 & 0,83 & 0,77 & 1,22 & 1,17 & $-3,992 * * *$ & $-3,834 * * *$ \\
\hline LQ*HFCF & 0,35 & 0,33 & 0,27 & 0,25 & $2,056^{* *}$ & $1,998 * *$ \\
\hline PER & 14,16 & 13,76 & 20,42 & 19,54 & $-2,385^{* *}$ & $-2,426^{* *}$ \\
\hline Liquidity & 1,48 & 1,35 & 2,02 & 1,97 & $-2,582 * * *$ & $-2,569 * * *$ \\
\hline
\end{tabular}

PtoP : Public to Private; SC : Sample Control

Notation: $* * * * *, *$ represent significance level up to $1 \%, 5 \%$ and $10 \%$.

Taxation: amount of taxation (\%); Gearing: ratio between financials debt to shareholder funds, Managerial ownership: 1: when the equity held by managers represents over 25\% of shares of the company; 0 : otherwise; Institutional block-holder: 1: when the share of institutional shareholders is at least equal to 5\% of shares of the company; 0: otherwise; Corporation block-holder: 1: when the share of corporation shareholders is at least equal to 5\% of shares of the company; 0: otherwise; Family block-holder: 1: when the share of family shareholders is at least equal to $5 \%$ of shares of the company; 0: otherwise; Free Cash-flow: It is approximated by operating income before depreciation and amortization minus tax, interest and dividend payments (Lehn \& Poulsen, 1989); Q ratio: market capitalisation deflated by total assets; Q1/Q2: $Q$ ratio in the year before going private (at the last published accounts) divided by the $Q$ ratio in the previous year; Q1/Q3: $Q$ ratio in the year before going private divided by the $Q$ ratio two years before; $\boldsymbol{L} \boldsymbol{Q} * \boldsymbol{H} \boldsymbol{F C F}$ : is a dummy variable that takes a value of one if a firm had below median $Q$ and above median free cash-flow and zero otherwise; Ln (Sales); Prior takeover interest: dummy variable which equals 1 if there has been any takeover interest in the year leading up to the PTP announcement; Price earnings ratio; Liquidity: Ratio of assets less stock on financial debt.

\subsection{United States}

In Panel A, the Corporate Block-holder and the institutional block-holder are two major elements that characterize public to private. We note that the institutional block-holder factor is the key control block-holder. It is both the highest of the panel but also the highest compared to other geographical areas. It can be understood by the fact that the institutional block-holder comprises Private Equity deals, which are in the United States, largely developed and invest heavily in these companies. The Family block-holder does not seem to explain the PtoP in the United States like in the United Kingdom. Taking control is also a feature of public to private in the U.S. This result is the highest of the four zones. In the case of the United States, we cannot invoke the lack of growth in the sense that companies cannot reach their level of development, because, it is a country that despite the crisis, is a growth engine. Nevertheless, we can justify it by the fact that in the United States many companies are created, but many also have financial difficulties and they are often bought instead of disappearing.

In panel $\mathrm{B}$, we also note that the level of FCF, growth prospects, underpricing and liquidity are all the four of important factors. Note that the results are higher than those we had observed in both Europe and the United Kingdom. Moreover, leverage is lower for companies than for PtoP remained in stock quotation. This is also true for Europe and the United Kingdom. 
Table 4: Results for the USA (209 observations)

\begin{tabular}{|c|c|c|c|c|c|c|}
\hline $\begin{array}{c}\text { Variables } \\
\end{array}$ & PtoP Mean & Median & SC Mean & Median & t value & z statistic \\
\hline \multicolumn{7}{|c|}{ Panel A: Property and Control } \\
\hline Managerial Ownership & 0,54 & 1 & 0,62 & 1 & $-2,456 * *$ & $-2,417 * *$ \\
\hline Institutionnal Block-holder & 0,72 & 1 & 0,92 & 1 & $-2,879 * * *$ & $-2,764 * * *$ \\
\hline Corporate Block-holder & 0,64 & 1 & 0,89 & 1 & $-2,367 * *$ & $-2,298 * *$ \\
\hline Family Block-holder & 0,49 & 1 & 0,52 & 0 & $-0,987$ & $-0,873$ \\
\hline Takeover Defence & 0,65 & 1 & 0,61 & 1 & 1,005 & 0,996 \\
\hline \multicolumn{7}{|l|}{ Panel B: Performance } \\
\hline Taxation & 1,50 & 1,45 & 1,48 & 1,32 & 1,251 & 1,197 \\
\hline Gearing & 1,63 & 1,60 & 1,65 & 1,75 & $-1,145$ & $-1,126$ \\
\hline Free Cash-flow & 5,26 & 5,21 & 4,83 & 4,53 & $2,746^{* * *}$ & $2,684 * * *$ \\
\hline $\mathrm{Q}$ ratio & 0,77 & 0,71 & 1,53 & 1,44 & $-4,456 * * *$ & $-4,067 * * *$ \\
\hline Q1/Q2 & 0,85 & 0,78 & 1,15 & 1,09 & $-3,818 * * *$ & $-3,534 * * *$ \\
\hline Q1/Q3 & 0,81 & 0,72 & 1,26 & 1,21 & $-4,257 * * *$ & $-4,127 * * *$ \\
\hline LQ*HFCF & 0,46 & 0,41 & 0,33 & 0,27 & $2,224 * *$ & $2,158 * *$ \\
\hline PER & 13,24 & 12,76 & 28,65 & 27,54 & $-3,547 * * *$ & $-3,468 * * *$ \\
\hline Liquidity & 1,45 & 1,26 & 2,01 & 1,89 & $-2,652 * * *$ & $-2,592 * * *$ \\
\hline
\end{tabular}

PtoP : Public to Private; SC : Sample Control

Notation: $* * * * *, *$ represent significance level up to $1 \%, 5 \%$ and $10 \%$.

Taxation: amount of taxation (\%); Gearing: ratio between financials debt to shareholder funds, Managerial ownership: 1: when the equity held by managers represents over $25 \%$ of shares of the company; 0 : otherwise; Institutional block-holder: 1: when the share of institutional shareholders is at least equal to $5 \%$ of shares of the company; 0: otherwise; Corporation block-holder: 1: when the share of corporation shareholders is at least equal to $5 \%$ of shares of the company; 0: otherwise; Family block-holder: 1: when the share of family shareholders is at least equal to $5 \%$ of shares of the company; 0: otherwise; Free Cash-flow: It is approximated by operating income before depreciation and amortization minus tax, interest and dividend payments (Lehn \& Poulsen, 1989); Q ratio: market capitalisation deflated by total assets; Q1/Q2: $Q$ ratio in the year before going private (at the last published accounts) divided by the $Q$ ratio in the previous year; Q1/Q3: $Q$ ratio in the year before going private divided by the $Q$ ratio two years before; $\boldsymbol{L Q} * \boldsymbol{H} \boldsymbol{F C F}$ : is a dummy variable that takes a value of one if a firm had below median $Q$ and above median free cash-flow and zero otherwise; Ln (Sales); Prior takeover interest: dummy variable which equals 1 if there has been any takeover interest in the year leading up to the PTP announcement; Price earnings ratio; Liquidity: Ratio of assets less stock on financial debt.

\subsection{Asia}

In Panel A, the institutional Block-holder and the corporate block-holder are both important elements relating to the ownership and control of public to private companies. We find that for Asia, like the United States, the Institutional block-holder is the most representative block-holder. This observation is also justified by the increase of corporate investments in Private Equity. The Family block is not significant. Taking defence in Asia is not a determining factor for the public to private companies. This is justified by the fact that the development of public to private is still very recent, which limit the abundant supply of redemptions as companies suffer in other geographical areas.

In panel B, the same observation as the previous applies for Asia. We also note that the level of tax in Asia for PtoP is much higher than in other areas. In contrast, companies in PtoP have a low level of gearing relative to firms publicly traded. We also note that this difference is the most important of the entire sample. The tests for these two variables, taxation and gearing, appear very significant in Asia, in contrast to what we have observed in other areas. 
Table 5: Results for Univariate Analysis for Asia (71 observations)

\begin{tabular}{|c|c|c|c|c|c|c|}
\hline $\begin{array}{l}\text { Variables } \\
\end{array}$ & PtoP Mean & Median & SC Mean & Median & t value & z statistic \\
\hline \multicolumn{7}{|c|}{ Panel A: Property and Control } \\
\hline Managerial Ownership & 0,61 & 1 & 0,78 & 1 & $-2,662 * * *$ & $-2,687 * * *$ \\
\hline Institutionnal Block-holder & 0,62 & 1 & 0,85 & 1 & $-3,005 * * *$ & $-2,954 * * *$ \\
\hline Corporate Block-holder & 0,63 & 1 & 0,79 & 1 & $-2,458 * *$ & $-2,397 * *$ \\
\hline Family Block-holder & 0,53 & 0 & 0,55 & 0 & $-0,789$ & $-0,654$ \\
\hline Takeover Defence & 0,65 & 1 & 0,62 & 1 & 1,205 & 1,117 \\
\hline \multicolumn{7}{|l|}{ Panel B: Performance } \\
\hline Taxation & 1,90 & 1,83 & 1,60 & 1,56 & $3,421 * * *$ & $3,217 * * *$ \\
\hline Gearing & 1,54 & 1,72 & 1,82 & 1,75 & $-2,896 * * *$ & $-2,746 * * *$ \\
\hline Free Cash-flow & 4,23 & 4,02 & 3,97 & 3,83 & $4,569 * * *$ & $4,327 * * *$ \\
\hline Q ratio & 0,82 & 0,73 & 1,45 & 1,39 & $-4,787 * * *$ & $-4,654 * * *$ \\
\hline $\mathrm{Q} 1 / \mathrm{Q} 2$ & 0,88 & 0,81 & 1,15 & 1,08 & $-3,956 * * *$ & $-3,872 * * *$ \\
\hline Q1/Q3 & 0,83 & 0,70 & 1,19 & 1,07 & $-4,362 * * *$ & $-4,317 * * *$ \\
\hline LQ*HFCF & 0,42 & 0,40 & 0,28 & 0,25 & $2,178^{* *}$ & $2,113 * *$ \\
\hline PER & 16,45 & 15,92 & 26,36 & 25,73 & $-1,831^{*}$ & $-1,729 *$ \\
\hline Liquidity & 1,49 & 1,35 & 2,05 & 1,88 & $-2,685 * * *$ & $-2,695 * * *$ \\
\hline
\end{tabular}

PtoP : Public to Private; SC : Sample Control

Notation: $* * *, * * *$ represent significance level up to $1 \%, 5 \%$ and $10 \%$.

Taxation: amount of taxation (\%); Gearing: ratio between financials debt to shareholder funds, Managerial ownership: 1: when the equity held by managers represents over $25 \%$ of shares of the company; 0 : otherwise; Institutional block-holder: 1: when the share of institutional shareholders is at least equal to $5 \%$ of shares of the company; 0: otherwise; Corporation block-holder: 1: when the share of corporation shareholders is at least equal to $5 \%$ of shares of the company; 0: otherwise; Family block-holder: 1: when the share of family shareholders is at least equal to $5 \%$ of shares of the company; 0: otherwise; Free Cash-flow: It is approximated by operating income before depreciation and amortization minus tax, interest and dividend payments (Lehn \& Poulsen, 1989); Q ratio: market capitalisation deflated by total assets; Q1/Q2: $Q$ ratio in the year before going private (at the last published accounts) divided by the $Q$ ratio in the previous year; Q1/Q3: $Q$ ratio in the year before going private divided by the $Q$ ratio two years before; $\boldsymbol{L Q} * \boldsymbol{H} \boldsymbol{F C F}$ : is a dummy variable that takes a value of one if a firm had below median $Q$ and above median free cash-flow and zero otherwise; Ln (Sales); Prior takeover interest: dummy variable which equals 1 if there has been any takeover interest in the year leading up to the PTP announcement; Price earnings ratio; Liquidity: Ratio of assets less stock on financial debt.

\section{DISCUSSION}

\subsection{Tax Saving}

First, we note that there is undisputed evidence concerning the level of taxation and gearing. Indeed, we observe public to private companies have higher tax level than the listed companies. Moreover, the leverage of public to private companies is lower than those in control sample. This analysis confirms our hypothesis 1. However, these two variables are not significant. Only Asia has a high level of tax and a low gearing. These two variables are significant at $1 \%$ level.

\subsection{Realignment of interests}

In general, we find that the realignment of interests can explain why companies go out of quotation. Indeed, managers in the Public to Private are less represented (0.65 against 0.85 for the control sample of companies in Europe; 0.51 cons 0.68 for the United Kingdom; 0.54 cons 0.62 for the United States; 0.61 cons 0.78 for Asia) which proves that the corporation is not directed so efficiently and this leads to significant monitoring costs. Therefore, a stronger presence of managers within companies will realign the interests between actors. 


\subsection{Control}

For control, three blocks are studied: institutional, corporate and family block-holders. The presence of an important control will be an essential element to successful public to private; they will be well better directed. However we note that the family block-holder is more present in public to private transactions in Europe relative to other geographical areas. Indeed, the latter has a threshold of significance at $1 \%$ for family block-holder, which proves that the latter plays an important role in public to private transactions. This result confirms our analysis in the sense that Europe is the only geographical area in our sample where the industrial fabric of small and medium enterprises is the central link in industrial productivity: hence the presence of an important control within the Public to Private to optimize their performance. In general, the institutional block-holder holds the largest share and the greatest significance. This may justify the significant presence of institutional investors in corporate capital. Thus, the presence of a stronger control will allow the company to have better management.

\subsection{Free Cash-flow}

In line with our expectations, public to private have higher levels of Free Cash-flow much more important that company's public. This indicates that the excess cash own by these companies can repay the debt. These positive results are confirmed with other studies (Renneboog, Simons, Wright (2006)) but they do not present significant results. Bo Becker, Joshua Pollet (2008) realise a study in the USA for the decision to go private and they obtain the same results as our study (a positive and significant link between going private and the level of free cashflow).

\subsection{Growth Prospects}

The results of the univariate analysis show that public to private firms has lower $\mathrm{Q}$ ratios than listed firms, whatever the geographical areas. In addition, we also note that the $\mathrm{Q}$ ratio of public to private was down compared to those observed in the previous two years (this result is confirmed with variables Q1/Q2, Q1/Q3), while deals remained in stock prices had important $\mathrm{Q}$ ratios. This shows that the companies have low growth prospects of PtoP and therefore the output of the rating may be a solution in terms of viability. In addition, results for LQ * HFCF are superior to the public to private firms owned compared to the control sample. Finally, firms in PtoP have the distinction of having low $\mathrm{Q}$ ratios and important levels of Free Cash-flow.

\subsection{Anti-Takeover}

We find that firms that are the subject of takeover are effective greater incentive to delist. Indeed, fear of being redeemed, managers prefer to leave the stock market. However this result is not significant in the sample whatever the geographical area.

\subsection{Undervaluation}

Concerning the under-valuation, the PtoP companies, as described in our hypothesis 7, are more undervalued in relation to listed companies. The difference is significant for all geographical areas and especially the United States who show a threshold of $1 \%$. 


\subsection{Summary}

We summarize all our results in order to derive a profile of public to private that is to say the main features of PtoP operations and also a profile of PtoP from different geographical areas studied. Typical profile of a public to private of a general part and secondly a specific profile to geographical areas studied:

- Low managerial share within firms

- Low representation of control blocks

- $\quad$ Significant cash-flow

- Weak growth outlook

- $\quad$ Undervalued company

- $\quad$ Liquidity problem (low liquidity).

Now, we show the typical profiles of public to private for each geographical area. For this, we consider only the most significant results of our study by geographic region. The selection of these specific characteristics area have been carried out taking into account both the results of the univariate analysis and those binary logistic regression.

Table 6: Profile Of A Public To Private For Each Geographical Areas

\begin{tabular}{lllll}
\hline Countries & \multicolumn{1}{c}{ Europe } & \multicolumn{1}{c}{ United Kingdom } & \multicolumn{1}{c}{ USA } & \multicolumn{1}{c}{ Asia } \\
\hline Profiles & Low managerial share & Low managerial share & Very low share of Family & Importance of level \\
& Important role of Family & Low importance of & Block & taxation (specific for \\
& Block & Family Block & Importance of FCF & Asia) \\
& Low representation of & Importance of Free Cash- & Low Q ratio & Low gearing \\
& Corporate Block & flow & Low liquidity & Low role of Institutional \\
& Low growth prospects & Low Q ratio & & Block \\
& Low liquidity & Low liquidity & & Importance of FCF \\
& & & Low Q ratio \\
& & & Low liquidity \\
\hline
\end{tabular}

\section{CONCLUSION}

In the last years, there was an increase of public to private transactions in the world. For certain geographical areas this phenomenon is not new while for others this phenomenon is rather recent. The USA and the United Kingdom are the precursors, Europe countries have now more and more PtoP and Asia knows these transactions since the early 2000's. To better understand this phenomenon, we realized an international empirical investigation to know the motivations of the companies to go private are. We show that low managerial share within societies, low representation of control blocks, significant cash-flow, weak growth outlook, undervalued company, liquidity problem are the main motivations for a company to delist. Moreover, our findings allowed us to construct a typical profile of a public to private transactions in each geographical area.

\section{AUTHOR INFORMATION}

Dr. Aurélie Sannajust is an Assistant Professor at the Université de Saint-Etienne and a Researcher at COACTIS, France. Her research focuses on corporate finance. She published in Bankers, Markets \& Investors and European Business Review. E-mail: aurelie.sannajust@univ-st-etienne.fr

Dr. Mohamed Arouri is a Researcher at EDHEC Business School, France. His research focuses on the cost of capital, energy economics, stock market integration, and international portfolio choice. He published articles in refereed journals such as Journal of Banking \& Finance, Journal of International Money \& Finance and La Revue Finance. E-mail: Mohamed.arouri@gmail.com (corresponding author)

Dr. Frédéric Teulon is a Professor and Dean of Research at IPAG Business School, France. His research focuses on the energy economics and finance. He published articles in refereed journals such as International Review of Financial Analysis, Energy Economics and Energy Policy. E-mail: f.teulon@ipag.fr 


\section{REFERENCES}

Andres, C., 2008, Large shareholders and firm performance an empirical examination of founding-family ownership, Journal of Corporate Finance, Vol. 14, pp.431-45.

Amihud, Y., Mendelson, H., 1998, Liquidity and assets prices: Financial management implications, Financial Mangement, 5-15

Berle, A., Means, G.C., 1932, The modern corporation and private property, New York Macmillan

Bo Becker, Joshua Pollet, 2008, The decision to go private, Working Paper

Calcagno, R., Rennebooh, L., 2007, The incentive to give incentives: on the relative seniority of debt claims and managerial compensation, Journal of Banking and Finance, 31(6), 1795-1815

Cotter J., Peck, S., 2001, The Structure of debt and active equity investors: the case of the buyout specialist, Journal of Financial Economics, 59, 101-147

DeAngelo, H., DeAngelo, L., Rice, E., 1984, Shareholder wealth and going private, Journal of Law and Economics, 27, 367-402

DeAngelo, L., 1986, Accounting numbers as market valuation substitutes: a study of management buy-outs if public stockholders, Accounting Review, 61, 400-420

Easterbrook, F.H., Fischel, D.R., 1983, Voting in Corporate Law, Journal of Law and Economics, 26, 395-428

Faccio, M. and Lang, L. H. P., 2002, The ultimate ownership of Western European corporations, Journal of Financial Economics, Vol. 65, , pp. 365-95.

Fenn, G.W., Liang, N., Prowse, S., 1995, The economics of the private equity market, Federal Reserve System Staff Paper

Franks, J., Mayer, C., Renneboog, L., 2001, Who disciplines management of poorly performing companies?, Journal of Financial Intermediation, 10, 209-248

Geranio, Zanotii (2007), Equity markets don't gill all companies: an analysis of public-to-private deals in Continental Europe, Working paper, SDA Bocconi

Goergen, M., Renneboog, L., 2004, Shareholder wealth effects of European domestic and cross-border takeover bids, European Financial Management Journal, 10, 9-45

Grossman, S.J., Hart, O.D., 1988, One-share vote and the market of corporate control, Journal of Financial Economics, 20, 175-202

Halpern, P., Kieschnick, R., Rotenberg, W., 1999, On the heterogeneity of leveraged going private transactions, Review of Financial Studies, 12, 281-309

Harlow, W.V., Howe, J.S., 1993, Leveraged buyouts and insider nontrading, Financial Management, 22, 109-118

Hubbard, G., Palia, D., 1995, Benefits of control, managerial ownership and the stock returns of acquiring firms, RAND Journal of Economics, 26, 782-794

Jensen, M.C., 1986, Agency costs of free cash-flow corporate finance and takeovers, American Economic Review, 76, 323-329

Jensen, M.C., 1989, The eclipse of the public corporation, Harvard Business Review, 67, 61-74

Jensen, M.C., Meckling, W., 1976, Theory of the firm: managerial behavior, agency costs and ownership structure, Journal of Financial Economics, 3, 305-360

Jensen, M.C., Ruback, R.S., 1983, The market for corporate control: the scientific evidence, Journal of Financial Economics, 11, 5-50

Jensen, M.C., Kaplan S., Stiglin, L., 1989, Effects of LBOs on tax revenues of the US treasury, Tax Notes, 42, 727733

Kaestner, R., Liu, F.Y., 1996, Going private restructuring: the role of insider trading, Journal of Business Finance and Accounting, 23, 779-806

Kaplan, S.N., 1989a, The effects of management buyouts on operating performance and value, Journal of Financial Economics, 24, 217-254

Kaplan, S.N., 1989b, Management buyouts: evidence on taxes as a source of value, Journal of Finance, 44, 611-632

Kaplan, S.N., 1991, The staying power of leveraged buyouts, Journal of Financial Economics, 29, 287-313

Kaplan, S.N., 1993, The staying power of leveraged buyouts, Journal of Applied Corporate Finance, 6, 15-24

Kaplan, S.N., Stein, J., 1993, The evolution of buyouts pricing and financial structure in the 1980s, Quartely Journal of Economics, 108, 313-359

Kennedy, V., Limcnack, 1996, Takeover activity, CEO turnover, and the market for corporate control, Journal of Business Finance and Accounting, 23, 267-293 
Kieschnick, R.L., 1989, Management buyouts of public corporations: an analysis of prior characteristics, Leveraged Management buy-outs, New York: Dow-Jones Irwin

Kothari, S.P., Warner, J.B., 1997, Measuring long-horizon security performance, Journal of Financial Economics, 43, 301-339

Lehn, K., Poulsen, A., 1989, Free Cash-flow and stockholder gains in going private transactions, Journal of Finance, 44, 771-788

Lehn, K., Netter, J. Poulsen, A., 1990, Consolidating corporate control: dual class recapitalizations versus leveraged buyouts, Journal of Financial Economics, 27, 73-88

Lowenstein, L., 1985, Management buyouts, Columbia Law Review, 85, 730-784

Martin, K.J., McConnel, J.J., 1991, Corporate Performance, corporate takeovers and management turnover, Journal of Finance, 42, 671-687

Maug, E., 1998, Large shareholders as monitors: is there a trade-off between liquidity and control ?, Journal of Finance, 53, 65-98

McConnell, J.J., Servaes, H., 1990, Additional evidence on equity ownership and corporate value, Journal of Financial Economics, 27, 595-612

Mehran, H., Peristiani, S., 2006, Financial visibility and the decision to go private, FED, Working paper

Morck, R., Shleifer, A., Vishny, R.W., 1998, Mangement ownership and market valuation: an empirical analysis, Journal of Financial Economics, 20, 293-315

Murphy, K.J., 1985, Corporate Performance and managerial remuneration: an empirical analysis, Journal of Accounting and Economics, 7, 11-42

Opler, T., Titman, S., 1993, The determinants of leveraged buyout activity, free cash-flow versus financial distress costs, Journal of Finance, 48, 1985-1999

Renneboog, L., Simons, T., 2005, Public to Private transactions: LBOs, MBOs, MBIs and IBOs, ECGI Finance Working Paper, 94

Renneboog, L., Simons, T.,Wright, M., 2006, Public to Private transactions in the UK, Working paper, Tilburg University

Roll, R., 1977, A critic of the pricing theory's tests, Journal of Financial Economics, 879-888

Sannajust, 2010, Motivations and performance of public to private transactions: an international study, Journal of Modern Accounting and Auditing, 6, n 9

Schadler, F.P., Karns, J.E., 1990, The unethical exploitation of shareholders in management buyout transactions, Journal of Business Ethics, 9, 595-602

Smith, A., 1776, The wealth of nations, Glasgow

Smith A., 1990, Capital ownership structure and performance: the case of management buy-outs, Journal of Financial Economics, 13, 143-165

Toms, S., Wright, M., 2004, Divergence and convergence within Anglo-American corporate governance systems: evidence from the US and UK 1950-2000, Business History, 47 (2), 267-295

Weir, C., Laing, D., Wright, M., 2005, Public to Private takeovers and the market for corporate control, Working paper, University of Nottingham

White, H., 1980, A heteroskedasticity covariance matrix estimator and a direct test for heteroskedasticity, Econometrica, 48, 817-838

Wright, M., Chiplin, B., Robbie, K., Albringhton, M., 2000, The development of an organizational innovation: Management buy-outs in the UK, Business History, volume 42, pages 137-184

Wright, M. Renneboog, L.D.R., Simons, T., Scholes, L., 2006, Leveraged buyouts in the UK and continental Europe: restrospect and prospects, Discussion Paper 70, Tilburg University, Center of Economic Research 


\section{NOTES}

